\title{
Educação do corpo e identidade na imigração japonesa no pós-guerra (São Paulo, 1945-1950)
}

\author{
DOI, Igor C. (IC), GOIS JUNIOR, Edivaldo (PQ).
}

\begin{abstract}
Resumo
Um dos olhares possíveis sobre a cultura é aquele que se interessa pelos usos do corpo. Neste universo, as práticas corporais estão relacionadas com todo o modo de vida de uma população. O presente estudo analisa a promoção das práticas corporais no contexto de associações e sociedades de imigrantes japoneses no Estado São Paulo - que entendemos como espaços de educação não formal -, questionando a relação entre essas práticas e a identidade desses imigrantes. Trata-se de um estudo historiográfico do período 1945-50, que se usou dos jornais como fonte.
\end{abstract}

Palavras Chave: Educação do corpo, identidade, imigração japonesa.

\section{Introdução}

Após um período de acentuado nacionalismo na política brasileira (1930-45), os imigrantes japoneses, que como outros estavam sob a vigilância do governo, sobretudo por causa da Segunda Guerra, fundaram sociedades secretas para o fortalecimento da sua identidade nacional. Dessas sociedades, a que mais teve visibilidade foi a Shindô-Renmei, a Liga do Caminho dos Súditos (do Imperador), que logo veio a ser conhecida por liderar atentados terroristas contra os próprios patrícios. Além de reforçar a identidade nacional, essa e outras sociedades japonesas reuniam os chamados "vitoristas", que propagandeavam que o Japão não fora derrotado - ao contrário: estaria prestes a vencer a segunda guerra - e entendiam como traidores da pátria os "derrotistas".

É nesse contexto de intensa "negociação" de identidades na colônia japonesa que procuramos descobrir qual a importância das práticas corporais na manutenção da identidade desses imigrantes no estado São Paulo, através de uma revisão de literatura e da pesquisa em jornais do período escolhido (1945-50). Os jornais foram obtidos na Hemeroteca Digital da Biblioteca Nacional Digital (BNDigital).

\section{Resultados e Discussão}

Foram colhidos 340 artigos jornalísticos de 4 periódicos do período, tendo o Jornal de Notícias fornecido a amostra mais expressiva. A análise dos dados foi delimitada a 25 artigos jornalísticos selecionados a partir dos critérios de inclusão que residiram nas temáticas sobre práticas corporais e identidade nacional, demonstrando que os imigrantes japoneses realizavam práticas corporais e estavam envolvidos em atividades esportivas no Brasil. Contudo, os documentos dão ênfase à participação dos imigrantes japoneses nas atividades de possível interesse aos brasileiros, como o atletismo, a natação e o beisebol. Vimos que a colônia japonesa foi tocada pelas exibições dos nadadores do Japão "peixes voadores" e que houve a fundação de uma sociedade esportiva na colônia de Marília-SP. Foi divulgada uma peça de teatro japonês no Jornal de Notícias e foi identificado, através de um inventário $^{2}$, um grupo de dança disposto a abrandar o conflito entre "vitoristas" e "derrotistas". Descobrimos ainda que a ShindôRenmei mantinha atividades de artes marciais ${ }^{1}$.

\section{Conclusões}

Os resultados sugerem que os imigrantes japoneses eram reconhecidos, entre outras coisas, também pela sua participação em práticas corporais diversas, além de possuírem organizações esportivas próprias. O programa de artes marciais na maior sociedade secreta de reforço à identidade japonesa e o uso da dança como possível mediadora de conflitos e negociações da identidade japonesa reforçam a nossa hipótese da importância das práticas corporais na manutenção e fortalecimento da identidade nipônica. Contudo, mais estudos serão necessários para compreender melhor a relação entre práticas e identidade para os imigrantes japoneses.

\section{Agradecimentos}

O presente trabalho foi realizado com apoio do CNPq, Conselho Nacional de Desenvolvimento Científico e Tecnológico - Brasil.

\footnotetext{
${ }^{1}$ SOCIEDADE BRASILEIRA DE CULTURA JAPONESA. Uma epopéia moderna: 80 anos da Imigração Japonesa no Brasil. São Paulo: Hucitec, 1992.

${ }^{2}$ MIYAGI, A.; YAMASHIRO, I. 1 século de história em fotos: a comunidade okinawa no Brasil 1908 - 2008: centenário da imigração. São Paulo: Paulo’s, 2004.
} 